\title{
Electrical Vehicle Design and Modeling
}

\author{
Erik Schaltz \\ Aalborg University \\ Denmark
}

\section{Introduction}

Electric vehicles are by many seen as the cars of the future as they are high efficient, produces no local pollution, are silent, and can be used for power regulation by the grid operator. However, electric vehicles still have critical issues which need to be solved. The three main challenges are limited driving range, long charging time, and high cost. The three main challenges are all related to the battery package of the car. The battery package should both contain enough energy in order to have a certain driving range and it should also have a sufficient power capability for the accelerations and decelerations. In order to be able to estimate the energy consumption of an electric vehicles it is very important to have a proper model of the vehicle (Gao et al., 2007; Mapelli et al., 2010; Schaltz, 2010). The model of an electric vehicle is very complex as it contains many different components, e.g., transmission, electric machine, power electronics, and battery. Each component needs to be modeled properly in order prevent wrong conclusions. The design or rating of each component is a difficult task as the parameters of one component affect the power level of another one. There is therefore a risk that one component is rated inappropriate which might make the vehicle unnecessary expensive or inefficient. In this chapter a method for designing the power system of an electric vehicle is presented. The method insures that the requirements due to driving distance and acceleration is fulfilled.

The focus in this chapter will be on the modeling and design of the power system of a battery electric vehicle. Less attention will therefore be put on the selection of each component (electric machines, power electronics, batteries, etc.) of the power system as this is a very big task in it self. This chapter will therefore concentrate on the methodology of the modeling and design process. However, the method presented here is also suitable for other architectures and choice of components.

The chapter is organized as follows: After the introduction Section 2 describes the modeling of the electric vehicle, Section 3 presents the proposed design method, Section 4 provides a case study in order to demonstrate the proposed method, and Section 5 gives the conclusion remarks.

\section{Vehicle modeling}

\subsection{Architecture}

Many different architectures of an electric vehicle exist (Chan et al., 2010) as there are many possibilities, e.g., 1 to 4 electric machines, DC or AC machines, gearbox/no gearbox, high or 
low battery voltage, one or three phase charging, etc. However, in this chapter the architecture in Fig. 1 is chosen.

The purpose of the different components in Fig. 1 will here shortly be explained: The traction power of the wheels is delivered by the three phase electric machine. The torque of the left and right wheels are provided by a differential with also has a gear ratio in order to fit the high speed of the electric machine shaft to the lower speed of the wheels. The torque and speed of the machine are controlled by the inverter which inverts the battery DC voltage to a three phase $\mathrm{AC}$ voltage suitable for the electric machine. When analyzing the energy consumption of an electric vehicle it is important also to include the losses due to the components which not are a part of the power chain from the grid to the wheels. These losses are denoted as auxiliary loss and includes the lighting system, comfort system, safety systems, etc. During the regenerative braking it is important that the maximum voltage of the battery is not exceeded. For this reason a braking resistor is introduced. The rectifier rectifies the three phase voltages and currents of the grid to DC levels and the boost converter makes it possible to transfer power from the low voltage side of the rectifier to the high voltage side of the battery.

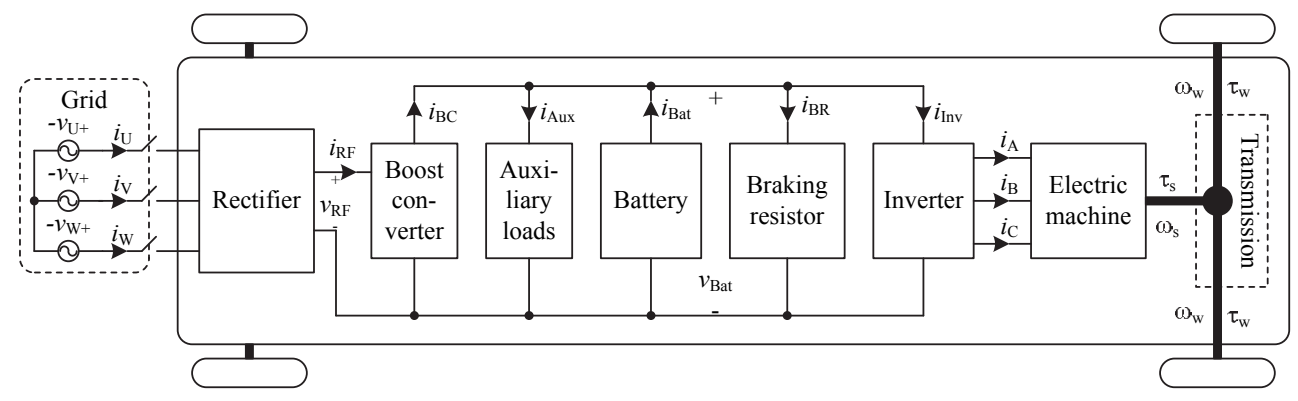

Fig. 1. Architecture of the battery electric vehicle. In the figure the main components of the vehicles which have an influence on the energy consumption of the vehicle is shown.

\subsection{Force Model}

The forces which the electric machine of the vehicle must overcome are the forces due to gravity, wind, rolling resistance, and inertial effect. These forces can also be seen in Fig. 2 where the forces acting on the vehicle are shown.

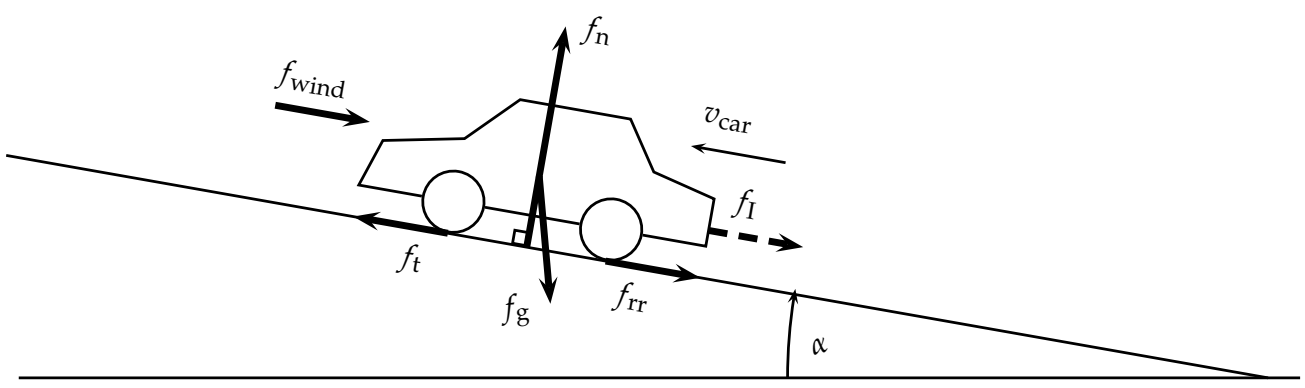

Fig. 2. Free body diagram of the forces (thick arrows) acting on the car. 
The traction force of a vehicle can be described by the following two equations (Ehsani et al., 2005):

$$
\begin{aligned}
f_{\mathrm{t}}= & \underbrace{M_{\mathrm{car}} \dot{v}_{\mathrm{car}}}_{f_{\mathrm{I}}}+\underbrace{M_{\mathrm{car}} \cdot g}_{f_{\mathrm{g}}} \cdot \sin (\alpha)+\operatorname{sign}\left(v_{\mathrm{car}}\right) \underbrace{\overbrace{M_{\mathrm{car}} \cdot g \cdot \cos (\alpha)}^{f_{\mathrm{n}}} \cdot c_{\mathrm{rr}}}_{f_{\mathrm{rr}}} \\
& +\operatorname{sign}\left(v_{\mathrm{car}}+v_{\text {wind }}\right) \underbrace{\frac{1}{2} \rho_{\text {air }} C_{\mathrm{drag}} A_{\text {front }}\left(v_{\mathrm{car}}+v_{\text {wind }}\right)^{2}}_{f_{\text {wind }}} \\
c_{\mathrm{rr}}= & 0.01\left(1+\frac{3.6}{100} v_{\mathrm{car}}\right),
\end{aligned}
$$

$\begin{array}{ccl}\text { where } f_{\mathrm{t}} & {[\mathrm{N}]} & \text { Traction force of the vehicle } \\ f_{\mathrm{I}} & {[\mathrm{N}]} & \text { Inertial force of the vehicle } \\ f_{\text {rr }} & {[\mathrm{N}]} & \text { Rolling resistance force of the wheels } \\ f_{\mathrm{g}} & {[\mathrm{N}]} & \text { Gravitational force of the vehicle } \\ f_{\mathrm{n}} & {[\mathrm{N}]} & \text { Normal force of the vehicle } \\ f_{\text {wind }} & {[\mathrm{N}]} & \text { Force due to wind resistance } \\ \alpha & {[\mathrm{rad}]} & \text { Angle of the driving surface } \\ M_{\text {car }} & {[\mathrm{kg}]} & \text { Mass of the vehicle } \\ v_{\text {car }} & {[\mathrm{m} / \mathrm{s}]} & \text { Velocity of the vehicle } \\ \dot{v}_{\text {car }} & {\left[\mathrm{m} / \mathrm{s}^{2}\right]} & \text { Acceleration of the vehicle } \\ g=9.81 & {\left[\mathrm{~m} / \mathrm{s}^{2}\right]} & \text { Free fall acceleration } \\ \rho_{\text {air }}=1.2041 & {\left[\mathrm{~kg} / \mathrm{m}^{3}\right]} & \text { Air density of dry air at } 20^{\circ} \mathrm{C} \\ c_{\text {rr }} & {[-]} & \text { Tire rolling resistance coefficient } \\ C_{\text {drag }} & {[-]} & \text { Aerodynamic drag coefficient } \\ A_{\text {front }} & {\left[\mathrm{m}^{2}\right]} & \text { Front area } \\ v_{\text {wind }} & {[\mathrm{m} / \mathrm{s}]} & \text { Headwind speed }\end{array}$

\subsection{Auxiliary loads}

The main purpose of the battery is to provide power for the wheels. However, a modern car have also other loads which the battery should supply. These loads are either due to safety, e.g., light, wipers, horn, etc. and/or comfort, e.g., radio, heating, air conditioning, etc. These loads are not constant, e.g., the power consumption of the climate system strongly depend on the surrounding temperature. Even though some average values are suggested which can be seen in Table 1. From the table it may be understood that the total average power consumption is $p_{\text {Aux }}=857 \mathrm{~W}$.

\begin{tabular}{|l|r|}
\hline Radio & $52 \mathrm{~W}$ \\
Heating Ventilation Air Condition (HVAC) & $489 \mathrm{~W}$ \\
Lights & $316 \mathrm{~W}$ \\
\hline Total $p_{\text {Aux }}$ & $857 \mathrm{~W}$ \\
\hline
\end{tabular}

Table 1. Average power level of the auxiliary loads of the vehicle. The values are inspired from (Ehsani et al., 2005; Emadi, 2005; Lukic \& Emadi, 2002). 


\subsection{Transmission}

From Fig. 1 it can be understood that the torque, angular velocity, and power of the transmission system are given by the following equations:

$$
\begin{aligned}
\tau_{\mathrm{t}} & =f_{\mathrm{t}} r_{\mathrm{w}} \\
\tau_{\mathrm{w}} & =\frac{\tau_{\mathrm{t}}}{2} \\
\omega_{\mathrm{w}} & =\frac{v_{\mathrm{car}}}{r_{\mathrm{w}}} \\
p_{\mathrm{t}} & =f_{\mathrm{t}} v_{\mathrm{car}},
\end{aligned}
$$

where $\tau_{\mathrm{t}} \quad[\mathrm{Nm}]$ Traction torque

$\tau_{\mathrm{W}} \quad[\mathrm{Nm}]$ Torque of each driving wheel

$r_{\mathrm{w}} \quad[\mathrm{m}]$ Wheel radius

$\omega_{\mathrm{w}}[\mathrm{rad} / \mathrm{s}]$ Angular velocity of the wheels

$p_{\mathrm{t}} \quad[\mathrm{W}]$ Traction power

It is assumed that the power from the shaft of the electric machine to the two driving wheels has a constant efficiency of $\eta_{\mathrm{TS}}=0.95$ (Ehsani et al., 2005). The shaft torque, angular velocity, and power of the electric machine are therefore

$$
\begin{aligned}
\tau_{\mathrm{s}} & =\left\{\begin{array}{l}
\eta_{\mathrm{TS}} \frac{\tau_{\mathrm{t}}}{G}, p_{\mathrm{t}}<0 \\
\frac{\tau_{\mathrm{t}}}{\eta_{\mathrm{TS}} G}, p_{\mathrm{t}} \geq 0
\end{array}\right. \\
\omega_{\mathrm{s}} & =G \omega_{\mathrm{w}} \\
p_{\mathrm{s}} & =\tau_{\mathrm{s}} \omega_{\mathrm{s}}
\end{aligned}
$$

where $\tau_{\mathrm{s}}[\mathrm{Nm}]$ Shaft torque of electric machine

$\omega_{\mathrm{s}}[\mathrm{rad} / \mathrm{s}]$ Shaft angular velocity of electric machine

$p_{\mathrm{S}} \quad[\mathrm{W}]$ Shaft power of electric machine

$G \quad[-] \quad$ Gear ratio of differential

\subsection{Electric machine}

For propulsion usually the induction machine (IM), permanent magnet synchronous machine (PMSM), and switched reluctance machine (SRM) are considered. The "best" choice is like many other components a trade off between, cost, mass, volume, efficiency, reliability, maintenance, etc. However, due to its high power density and high efficiency the PMSM is selected. The electric machine is divided into an electric part and mechanic part. The electric part of the PMSM is modeled in the DQ-frame, i.e.,

$$
\begin{aligned}
v_{\mathrm{d}} & =R_{\mathrm{s}} i_{\mathrm{d}}+L_{\mathrm{d}} \frac{d i_{\mathrm{d}}}{d t}-\omega_{e} L_{\mathrm{q}} i_{\mathrm{q}} \\
v_{\mathrm{q}} & =R_{\mathrm{s}} i_{\mathrm{q}}+L_{\mathrm{q}} \frac{d i_{\mathrm{q}}}{d t}+\omega_{e} L_{\mathrm{d}} i_{\mathrm{d}}+\omega_{\mathrm{e}} \lambda_{p m} \\
p_{\mathrm{EM}} & =\frac{3}{2}\left(v_{\mathrm{d}} i_{\mathrm{d}}+v_{\mathrm{q}} i_{\mathrm{q}}\right),
\end{aligned}
$$




$\begin{array}{cll}\text { where } v_{\mathrm{d}} & {[\mathrm{V}]} & \text { D-axis voltage } \\ v_{\mathrm{q}} & {[\mathrm{V}]} & \text { Q-axis voltage } \\ i_{\mathrm{d}} & {[\mathrm{A}]} & \text { D-axis current } \\ i_{\mathrm{q}} & {[\mathrm{A}]} & \text { Q-axis current } \\ R_{\mathrm{s}} & {[\Omega]} & \text { Stator phase resistance } \\ L_{\mathrm{d}} & {[\mathrm{H}]} & \text { D-axis inductance } \\ L_{\mathrm{q}} & {[\mathrm{H}]} & \text { Q-axis inductance } \\ \lambda_{\mathrm{pm}} & {[\mathrm{Wb}]} & \text { Permanent magnet flux linkage } \\ \omega_{\mathrm{e}} & {[\mathrm{rad} / \mathrm{s}]} & \text { Angular frequency of the stator } \\ \lambda_{\mathrm{pm}} & {[\mathrm{Wb}]} & \text { Permanent magnet flux linkage } \\ p_{\mathrm{EM}} & {[\mathrm{W}]} & \text { Electric input power }\end{array}$

The mechanical part of the PMSM can be modeled as follows:

$$
\begin{aligned}
& \tau_{\mathrm{e}}=J_{\mathrm{s}} \frac{d \omega_{\mathrm{s}}}{d t}+B_{\mathrm{v}} \omega_{\mathrm{s}}+\tau_{\mathrm{c}}+\tau_{\mathrm{s}} \\
& p_{\mathrm{s}}=\tau_{\mathrm{s}} \omega_{\mathrm{s}}
\end{aligned}
$$

where $J_{\mathrm{s}} \quad\left[\mathrm{kgm}^{2}\right] \quad$ Shaft moment of inertia

$\tau_{\mathrm{e}} \quad[\mathrm{Nm}] \quad$ Electromechanical torque

$\tau_{\mathrm{c}} \quad[\mathrm{Nm}] \quad$ Coulomb torque

$B_{\mathrm{V}}[\mathrm{Nms} / \mathrm{rad}]$ Viscous friction coefficient

The coupling between the electric and mechanic part is given by

$$
\begin{aligned}
\tau_{\mathrm{e}} & =\frac{3}{2} \frac{P}{2}\left(\lambda_{p m} i_{\mathrm{q}}+\left(L_{\mathrm{d}}-L_{\mathrm{q}}\right) i_{\mathrm{d}} i_{\mathrm{q}}\right) \\
\omega_{\mathrm{e}} & =\frac{P}{2} \omega_{\mathrm{s}},
\end{aligned}
$$

where $P[-]$ Number of poles

\subsection{Inverter}

A circuit diagram of the inverter can be seen in Fig. 3. The inverter transmits power between the electric machine (with phase voltages $v_{\mathrm{A}}, v_{\mathrm{B}}$, and $v_{\mathrm{C}}$ ) and the battery by turning on and

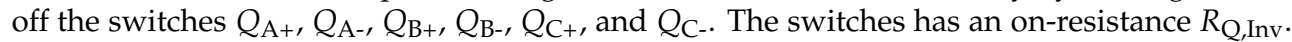
The diodes in parallel of each switch are creating a path for the motor currents during the deadtime, i.e., the time where both switches in one branch are non-conducting in order to avoid a shoot-through.

The average power losses of one switch $p_{\mathrm{Q}, \text { Inv }}$ and diode $p_{\mathrm{D} \text {,Inv }}$ in Fig. 3 during one fundamental period are (Casanellas, 1994):

$$
\begin{aligned}
p_{\mathrm{Q}, \text { Inv }} & =\left(\frac{1}{8}+\frac{m_{\mathrm{i}}}{3 \pi}\right) R_{\mathrm{Q}, \text { Inv }} \hat{I}_{\mathrm{p}}^{2}+\left(\frac{1}{2 \pi}+\frac{m_{\mathrm{i}}}{8} \cos \left(\phi_{\mathrm{EM}}\right)\right) V_{\mathrm{Q}, \text { th,Inv }} \hat{I}_{\mathrm{p}} \\
p_{\mathrm{D}, \text { Inv }} & =\left(\frac{1}{8}-\frac{m_{\mathrm{i}}}{3 \pi}\right) R_{\mathrm{D}, \text { Inv }} \hat{I}_{\mathrm{p}}^{2}+\left(\frac{1}{2 \pi}-\frac{m_{\mathrm{i}}}{8} \cos \left(\phi_{\mathrm{EM}}\right)\right) V_{\mathrm{D}, \text { th }, \text { Inv }} \hat{I}_{\mathrm{p}} \\
m_{\mathrm{i}} & =\frac{2 \widehat{V}_{\mathrm{p}}}{V_{\text {Bat }}}
\end{aligned}
$$




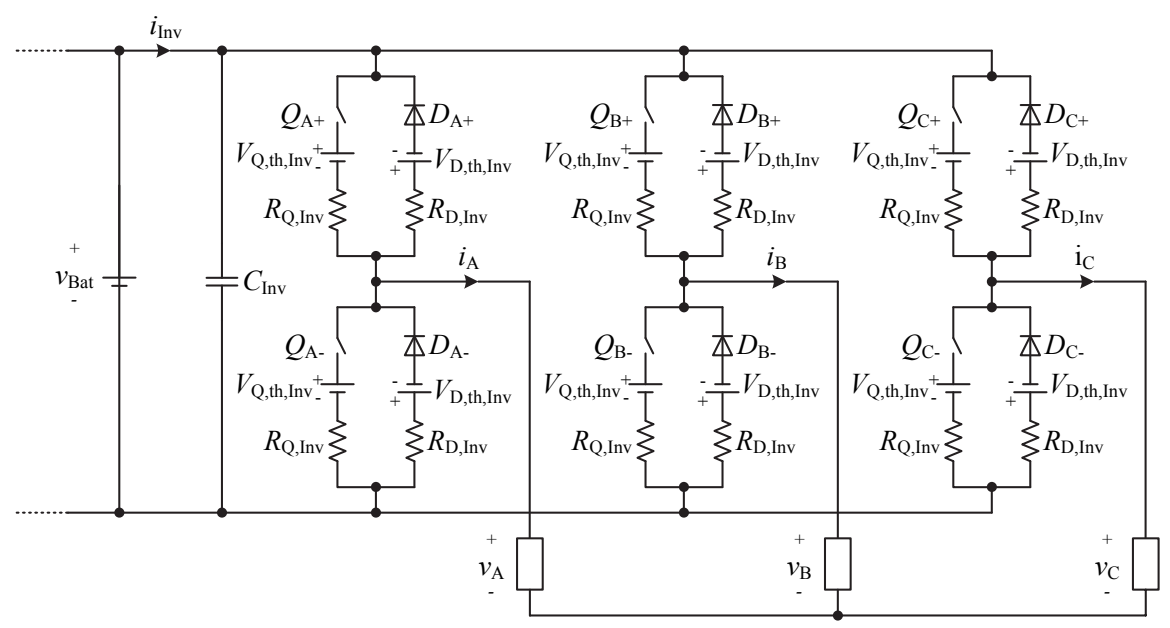

Fig. 3. Circuit diagram of inverter.

where $p_{\mathrm{Q}, \text { Inv }} \quad[\mathrm{W}]$ Power loss of one switch

$p_{\mathrm{D}, \mathrm{Inv}} \quad[\mathrm{W}]$ Power loss of one diode

$\phi_{\mathrm{EM}} \quad[\mathrm{rad}]$ Power factor angle

$\hat{I}_{\mathrm{p}} \quad[\mathrm{A}]$ Peak phase current

$\hat{V}_{\mathrm{p}} \quad[\mathrm{V}]$ Peak phase voltage

$m_{\mathrm{i}} \quad[-]$ Modulation index

$V_{\text {Bat }} \quad[\mathrm{V}]$ Battery voltage

$R_{\mathrm{Q}, \text { Inv }} \quad[\Omega]$ Inverter switch resistance

$R_{\mathrm{D}, \text { Inv }} \quad[\Omega]$ Inverter diode resistance

$V_{\mathrm{Q}, \text { th,Inv }}[\mathrm{V}]$ Inverter switch threshold voltage

$V_{\mathrm{D}, \text { th,Inv }} \quad[\mathrm{V}]$ Inverter diode threshold voltage

If it is assumed that the threshold voltage drop of the switches and diodes are equal, i.e., $V_{\mathrm{th}, \mathrm{Inv}}=V_{\mathrm{Q} \text {,th,Inv }}=V_{\mathrm{D} \text {,th,Inv, }}$, and that the resistances of the switches and diodes also are equal, i.e., $R_{\mathrm{Inv}}=R_{\mathrm{Q}, \mathrm{Inv}}=R_{\mathrm{D} \text {,Inv }}$, the total power loss of the inverter is given by

$$
P_{\text {Inv,loss }}=6\left(P_{\mathrm{Q}, \text { Inv }}+P_{\mathrm{D}, \text { Inv }}\right)=\frac{3}{2} R_{\operatorname{Inv}} \hat{I}_{\mathrm{p}}^{2}+\frac{6}{\pi} V_{\text {th,Inv }} \hat{I}_{\mathrm{p}} .
$$

The output power of the inverter is the motor input power $p_{\mathrm{EM}}$. The inverter input power and efficiency are therefore

$$
\begin{aligned}
& p_{\text {Inv }}=v_{\text {Bat }} i_{\text {Inv }}=p_{\mathrm{EM}}+p_{\text {Inv,loss }} \\
& \eta_{\text {Inv }}=\left\{\begin{array}{l}
\frac{p_{\mathrm{EM}}}{p_{\text {IIv }}}, p_{\mathrm{EM}} \geq 0 \\
\frac{\text { Inv }_{\mathrm{EM}}}{p_{\mathrm{EM}}}, p_{\mathrm{EM}}<0,
\end{array}\right.
\end{aligned}
$$

where $i_{\text {Inv }} \quad[\mathrm{A}]$ Inverter input current

$p_{\text {Inv }}[\mathrm{W}]$ Inverter input power

$\eta_{\text {Inv }}[-]$ Inverter efficiency 


\subsection{Battery}

The battery pack is the heart of an electric vehicle. Many different battery types exist, e.g., lead-acid, nickel-metal hydride, lithium ion, etc. However, today the lithium ion is the preferred choice due to its relatively high specific energy and power. In this chapter the battery model will be based on a Saft VL 37570 lithium ion cell. It's specifications can be seen in Table 2.

\begin{tabular}{|l|l|r|}
\hline Maximum voltage & $V_{\text {Bat,max,cell }}$ & $4.2 \mathrm{~V}$ \\
Nominal voltage & $V_{\text {Bat,nom,cell }}$ & $3.7 \mathrm{~V}$ \\
Minimum voltage & $V_{\text {Bat,min,cell }}$ & $2.5 \mathrm{~V}$ \\
$1 \mathrm{~h}$ capacity & $Q_{1, \text { cell }}$ & $7 \mathrm{Ah}$ \\
Nominal 1 $\mathrm{h}$ discharge current & $I_{\text {Bat,1,cell }}$ & $7 \mathrm{~A}$ \\
Maximum pulse discharge current & $I_{\text {Bat,max,cell }}$ & $28 \mathrm{~A}$ \\
\hline
\end{tabular}

Table 2. Data sheet specifications of Saft VL 37570 LiIon battery (Saft, 2010).

\subsubsection{Electric model}

The battery will only be modeled in steady-state, i.e., the dynamic behavior is not considered. The electric equivalent circuit diagram can be seen in Fig.4. The battery model consist of an internal voltage source and two inner resistances used for charging and discharging. The two diodes are ideal and have only symbolics meaning, i.e., to be able to shift between the charging and discharging resistances. Discharging currents are treated as positive currents, i.e., charging currents are then negative.

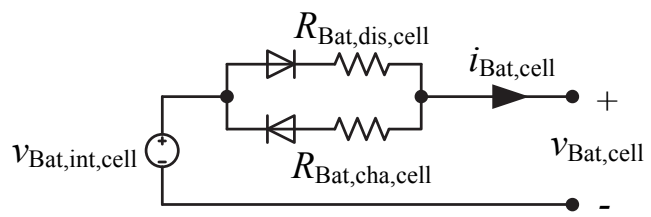

Fig. 4. Electric equivalent circuit diagram of a battery cell.

From Fig. 4 the cell voltage is therefore given by

$$
v_{\text {Bat,cell }}=\left\{\begin{array}{l}
v_{\text {Bat,int,cell }}-R_{\text {Bat,cell,dis }} i_{\text {Bat,cell }}, i_{\text {Bat,cell }} \geq 0 \\
v_{\text {Bat,int,cell }}-R_{\text {Bat,cell,cha }} i_{\text {Bat,cell }}, i_{\text {Bat,cell }}<0,
\end{array}\right.
$$

$$
\begin{array}{ll}
\text { where } v_{\text {Bat,cell }} & {[\mathrm{V}] \text { Battery cell voltage }} \\
v_{\text {Bat,int,cell }} & {[\mathrm{V}] \text { Internal battery cell voltage }} \\
i_{\text {Bat,cell }} & {[\mathrm{A}] \text { Battery cell current }} \\
R_{\text {Bat,cell,dis }} & {[\Omega] \text { Inner battery cell resistance during discharge mode }} \\
R_{\text {Bat,cell,cha }} & {[\Omega] \text { Inner battery cell resistance during charge mode }}
\end{array}
$$

The inner voltage source and the two resistances in Fig. 4 depend on the depth-of-discharge of the battery. The battery cell have been modeled by the curves given in the data sheet of the battery. It turns out that the voltage source and the resistances can be described as $10^{\text {th }}$ order polynomials, i.e.,

$$
\begin{aligned}
R_{\text {Bat,cell,dis }}= & a_{10} D o D_{\text {Bat }}^{10}+a_{9} D o D_{\text {Bat }}^{9}+a_{8} D o D_{\text {Bat }}^{8}+a_{7} D o D_{\text {Bat }}^{7}+a_{6} D o D_{\text {Bat }}^{6} \\
& +a_{5} D o D_{\text {Bat }}^{5}+a_{4} D o D_{\text {Bat }}^{4}+a_{3} D o D_{\text {Bat }}^{3}+a_{2} D o D_{\text {Bat }}^{2}+a_{1} D o D_{\text {Bat }}+a_{0}
\end{aligned}
$$




$$
\begin{aligned}
v_{\text {Bat,int,cell }}= & b_{10} D o D_{\text {Bat }}^{10}+b_{9} D o D_{\text {Bat }}^{9}+b_{8} D o D_{\text {Bat }}^{8}+b_{7} D o D_{\text {Bat }}^{7}+b_{6} D o D_{\text {Bat }}^{6} \\
& +b_{5} D o D_{\text {Bat }}^{5}+b_{4} D o D_{\text {Bat }}^{4}+b_{3} D o D_{\text {Bat }}^{3}+b_{2} D o D_{\text {Bat }}^{2}+b_{1} D o D_{\text {Bat }}+b_{0} \\
R_{\text {Bat,cell,cha }}= & c_{10} D o D_{\text {Bat }}^{10}+c_{9} D o D_{\text {Bat }}^{9}+c_{8} D o D_{\text {Bat }}^{8}+c_{7} D o D_{\text {Bat }}^{7}+c_{6} D o D_{\text {Bat }}^{6} \\
& +c_{5} D o D_{\text {Bat }}^{5}+c_{4} D o D_{\text {Bat }}^{4}+c_{3} D o D_{\text {Bat }}^{3}+c_{2} D o D_{\text {Bat }}^{2}+c_{1} D o D_{\text {Bat }}+c_{0}
\end{aligned}
$$

where $a_{10}=-634.0, a_{9}=2942.1, a_{8}=-5790.6, a_{7}=6297.4, a_{6}=-4132.1, a_{5}=1677.7$

$$
\begin{aligned}
& a_{4}=-416.4, a_{3}=60.5, \quad a_{2}=-4.8, \quad a_{1}=0.2, \quad a_{0}=0.0 \\
& b_{10}=-8848, b_{9}=40727, b_{8}=-79586, b_{7}=86018, b_{6}=-56135, b_{5}=-5565 \\
& b_{4}=784, \quad b_{3}=-25, \quad b_{2}=55, \quad b_{1}=0, \quad b_{0}=4 \\
& c_{10}=2056, \quad c_{9}=-9176, \quad c_{8}=17147, \quad c_{7}=-17330, c_{6}=10168, \quad c_{5}=-3415 \\
& c_{4}=578, \quad c_{3}=25, \quad c_{2}=3, \quad c_{1}=0, \quad c_{0}=0
\end{aligned}
$$

\subsubsection{Capacity model}

The inner voltage source, charging resistance, and discharge resistance all depend on the depth-of-discharge. The state-of-charge and depth-of-discharge depend on the integral of the current drawn or delivered to the battery, i.e.,

$$
\begin{aligned}
D o D_{\text {Bat }} & =D o D_{\text {Bat,ini }}+\int \frac{i_{\text {Bat,eq,eell }}}{Q_{\text {Bat, } 1, \text { cell }}} d t \\
S o C_{\text {Bat }} & =1-D o D_{\text {Bat }}
\end{aligned}
$$

where $D o D_{\text {Bat }} \quad[-]$ Depth-of-discharge

$D o D_{\text {Bat,ini }}[-]$ Initial depth-of-discharge

So $C_{\text {Bat }}[-]$ Battery state-of-charge

$i_{\text {Bat,eq,ell }} \quad[\mathrm{A}]$ Equivalent battery cell current

The equivalent battery cell current depend on the sign and amplitude of the current (Schaltz, 2010). Therefore

$$
\begin{aligned}
i_{\text {Bat,eq,cell }} & = \begin{cases}I_{\text {Bat }, 1, \text { cell }}\left(\frac{i_{\text {Bat,cell }}}{I_{\text {Bat }, 1, \text { ell }}}\right)^{k}, & i_{\text {Bat,cell }} \geq 0 \\
\eta_{\text {Bat,cha }} i_{\text {Bat,cell }}, & i_{\text {Bat,cell }}<0\end{cases} \\
k & = \begin{cases}1, & i_{\text {Bat,cell }} \leq I_{\text {Bat }, 1, \text { cell }} \\
1.125, & i_{\text {Bat,cell }}>I_{\text {Bat }, 1, \text { cell }}\end{cases}
\end{aligned}
$$

where $k$

$$
k \quad[-] \text { Peukert number }
$$

It is seen that the peukert number has two different values depending on the amplitude of the discharge current. For currents higher than the nominal 1 hour discharge current $I_{\text {Bat, } 1, \text { cell }}$ the capacity is therefore reduced significant.

\subsubsection{Simulation results}

In order to verify the methods used to calculate the state-of-charge, internal voltage source, and charging resistance calculations are compared to the data sheet values. The results can be seen in Fig. 5 where the battery cell voltage is shown for different $C$-values $(1 \mathrm{C}$ is the nominal discharge current of $I_{\text {Bat, } 1, \text { cell }}=7 \mathrm{~A}$, which means that $\mathrm{C} / 2$ is equal to $3.5 \mathrm{~A}$ ). It is seen that the calculated voltages almost are identical to the data sheet values. It is also noticed that the voltage is strongly depending on the current level and the delivered Ah, and that the voltage drops significant when the battery is almost completely discharged. 




Fig. 5. Data sheet values (Saft, 2010) and calculations of the battery voltage during constant discharge currents.

\subsection{Boost converter}

The circuit diagram of the boost converter can be seen in Fig. 6. The losses of the boost

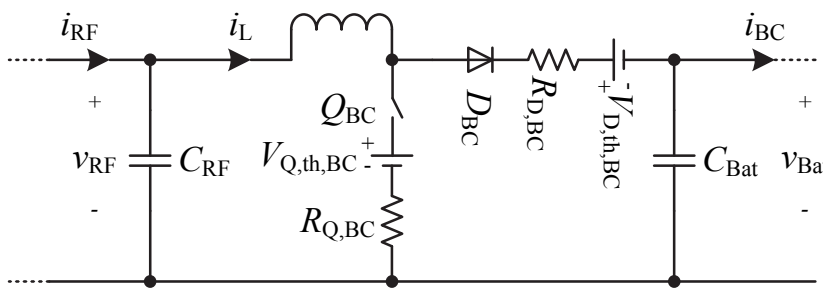

Fig. 6. Electric circuit diagram of the boost converter.

converter are due to the switch resistance $R_{\mathrm{Q}, \mathrm{BC}}$ and threshold voltage $V_{\mathrm{Q}, \text { th,BC }}$ and the diodes resistance $R_{\mathrm{D}, \mathrm{BC}}$ and threshold voltage $V_{\mathrm{D}, \mathrm{th}, \mathrm{BC}}$. In order to simplify it is assumed that the resistances and threshold voltages of the switch $Q_{\mathrm{BC}}$ and diode $D_{\mathrm{BC}}$ are equal, i.e., $R_{\mathrm{BC}}=R_{\mathrm{Q}, \mathrm{BC}}=R_{\mathrm{D}, \mathrm{RF}}$ and $V_{\mathrm{th}, \mathrm{BC}}=V_{\mathrm{Q}, \mathrm{th}, \mathrm{BC}}=V_{\mathrm{D}, \mathrm{th}, \mathrm{BC}}$. The power equations of the boost converter are therefore given by

$$
\begin{aligned}
P_{\mathrm{RF}} & =V_{\mathrm{RF}} i_{\mathrm{RF}}=P_{\mathrm{BC}}+P_{\mathrm{Loss}, \mathrm{BC}} \\
P_{\mathrm{BC}} & =V_{\mathrm{Bat}} i_{\mathrm{BC}} \\
P_{\mathrm{Loss}, \mathrm{BC}} & =R_{\mathrm{BC}} i_{\mathrm{RF}}^{2}+V_{\mathrm{th}, \mathrm{BC}} i_{\mathrm{RF}},
\end{aligned}
$$




\begin{tabular}{|c|c|}
\hline here $P_{\mathrm{RF}}$ & {$[\mathrm{W}]$ Input power of boost converter } \\
\hline$P_{\mathrm{BC}}$ & [W] Output power of boost converter \\
\hline$P_{\text {Loss,BC }}$ & [W] Power loss of boost converter \\
\hline$V_{\mathrm{RF}}$ & [V] Input voltage of boost converter \\
\hline$V_{\text {th, BC }}$ & [V] Threshold voltage of switch and diode \\
\hline$R_{\mathrm{BC}}$ & {$[\Omega]$ Resistance of switch and diode } \\
\hline$i_{\mathrm{RF}}$ & [A] Input current of boost converter \\
\hline$i_{\mathrm{BC}}$ & [A] Output current of boost converter \\
\hline
\end{tabular}

\subsection{Rectifier}

In order to utilize the three phase voltages of the grid $v_{\mathrm{U}}, v_{\mathrm{V}}$, and $v_{\mathrm{W}}$ they are rectified by a rectifier as seen in Fig. 7. In the rectifier the loss is due to the resistance $R_{\mathrm{D}, \mathrm{RF}}$ and threshold voltage $V_{\mathrm{D}, \text { th, RF }}$.

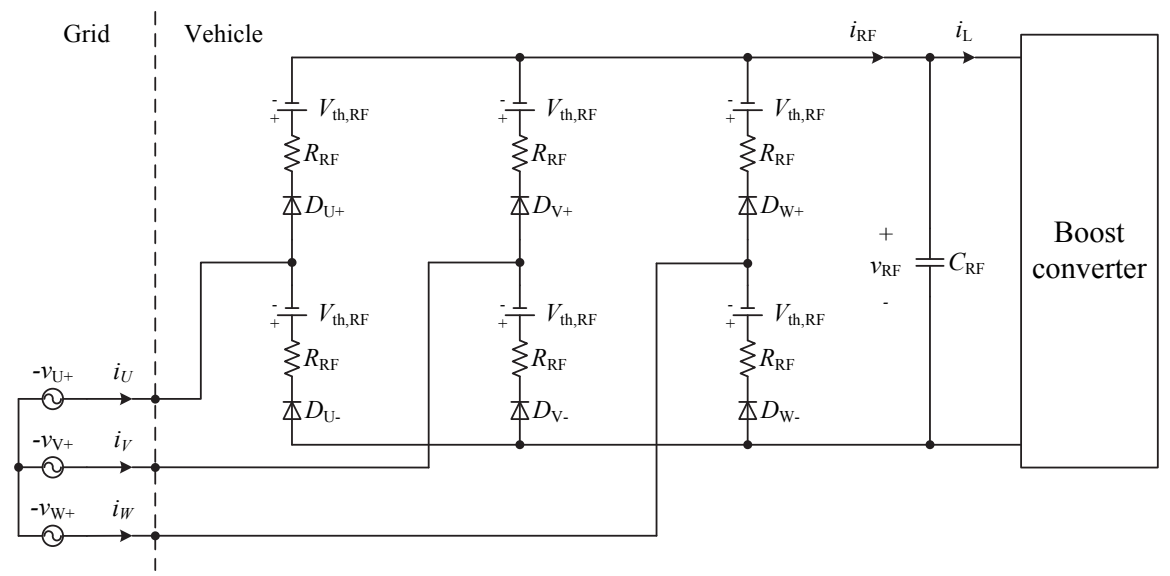

Fig. 7. Electric circuit diagram of the rectifier.

The average rectified current, voltage, and power are given by (Mohan et al., 2003)

$$
\begin{gathered}
i_{\mathrm{RF}}=I_{\mathrm{Grid}} \sqrt{\frac{3}{2}} \\
V_{\mathrm{RF}}=\frac{3 \sqrt{2}}{\pi} V_{\mathrm{LL}}-2 R_{\mathrm{RF}} i_{\mathrm{RF}}-2 V_{\mathrm{th}, \mathrm{RF}} \\
P_{\mathrm{RF}}=V_{\mathrm{RF}} i_{\mathrm{RF}}=P_{\mathrm{Grid}}-P_{\mathrm{RF}, \text { loss }} \\
P_{\mathrm{Grid}}=\frac{3 \sqrt{2}}{\pi} V_{\mathrm{LL}} I_{\mathrm{RF}} \\
P_{\mathrm{RF}, \text { loss }}=2 R_{\mathrm{RF}} i_{\mathrm{RF}}^{2}+2 V_{\mathrm{th}, \mathrm{RF}} i_{\mathrm{RF}},
\end{gathered}
$$

where $I_{\text {Grid }} \quad[\mathrm{A}]$ Grid RMS-current

$P_{\text {Grid }} \quad[\mathrm{W}]$ Power of three phase grid

$P_{\text {loss,RF }}[\mathrm{W}]$ Total loss of the rectifier

$R_{\mathrm{RF}} \quad[\Omega]$ Resistance of switch and diode

$V_{\mathrm{th}, \mathrm{RF}} \quad[\mathrm{V}]$ Threshold voltage of switch and diode 


\subsection{Simulation model}

The models of each component of the power system in the electric vehicle have now been explained. When combining all the sub models a model of the battery electric vehicle is obtained. In Fig. 8 the implementation in a Matlab/Simulink environment can be seen. The overall vehicle model includes the model of the forces acting on the vehicle (wind, gravity, rolling resistance, etc.), and the individual components of the power train, i.e., transmission, electric machine, inverter, battery, boost converter, rectifier. The wind speed $v_{\text {wind }}$ and road angle $\alpha$ have been set to zero for simplicity. The input to the simulation model is a driving cycle (will be explained in Section 4) and the output of the model is all the currents, voltages, powers, torques, etc, inside the vehicle.

\section{Design method}

\subsection{Parameter determination}

The parameter determination of the components in the vehicle is an iterative process. The parameters are calculated by using the models given in Section 2 and the outputs of the Matlab/Simulink model shown in Fig. 8.

\subsubsection{Battery}

The maximum rectified voltage can be calculated from Equation 35 in no-load mode, i.e.,

$$
V_{\mathrm{RF}, \max }=\frac{3 \sqrt{2}}{\pi} V_{L L}=\frac{3 \sqrt{2}}{\pi} 400 \mathrm{~V}=540 \mathrm{~V} .
$$

In order to insure boost operation during charging the rectified voltage of the rectifier should always be greater than this value. The required number of series connected cells is therefore

$$
N_{\text {Bat }, \mathrm{s}}=\frac{V_{\mathrm{RF}, \max }}{V_{\text {Bat,cell,min }}}=\frac{540 \mathrm{~V}}{2.5 \mathrm{~V}} \approx 216 \text { cells. }
$$

The number of series connected cells $N_{\mathrm{Bat}, \mathrm{s}}$ is due to the voltage requirement of the battery pack. However, in order to insure that the battery pack contains sufficient power and energy it is probably not enough with only one string of series connected cells. The battery pack will therefore consist of $N_{\text {Bat,s }}$ series connected cells and $N_{\text {Bat,p }}$ parallel strings. The number of parallel strings $N_{\text {Bat,p }}$ are calculated in an iterative process. The flow chart of the sizing procedure of the battery electric vehicle can be seen in Fig. 9. In the "Initialization"-process the base parameters are defined, e.g., wheel radius and nominal bus voltage, initial power ratings of each component of the vehicle are given, and the base driving cycle is loaded into the workspace of Matlab. In the "Is the minimum number of parallel strings obtained?"-decision block it is verified if the minimum number of parallel strings that fulfills both the energy and power requirements of the battery have been reached. If not a "Simulation routine"-process is executed. This process are executed several times during the sizing procedure and its flow chart is therefore shown separately in Fig. 9. This process consist of three sub-processes. The first sub-process is "Design components". In this process the parameters of each component of the battery electric vehicle are determined, e.g., motor and power electronic parameters. The next sub-process is the "Vehicle simulation"-process. In this process the Simulink-model of the vehicle is executed due to the parameters specified in the previous sub-process. In the third and last sub-process, i.e., the "Calculate the power and energy of each component"-process, the energy and power of each component of the vehicle are calculated. 


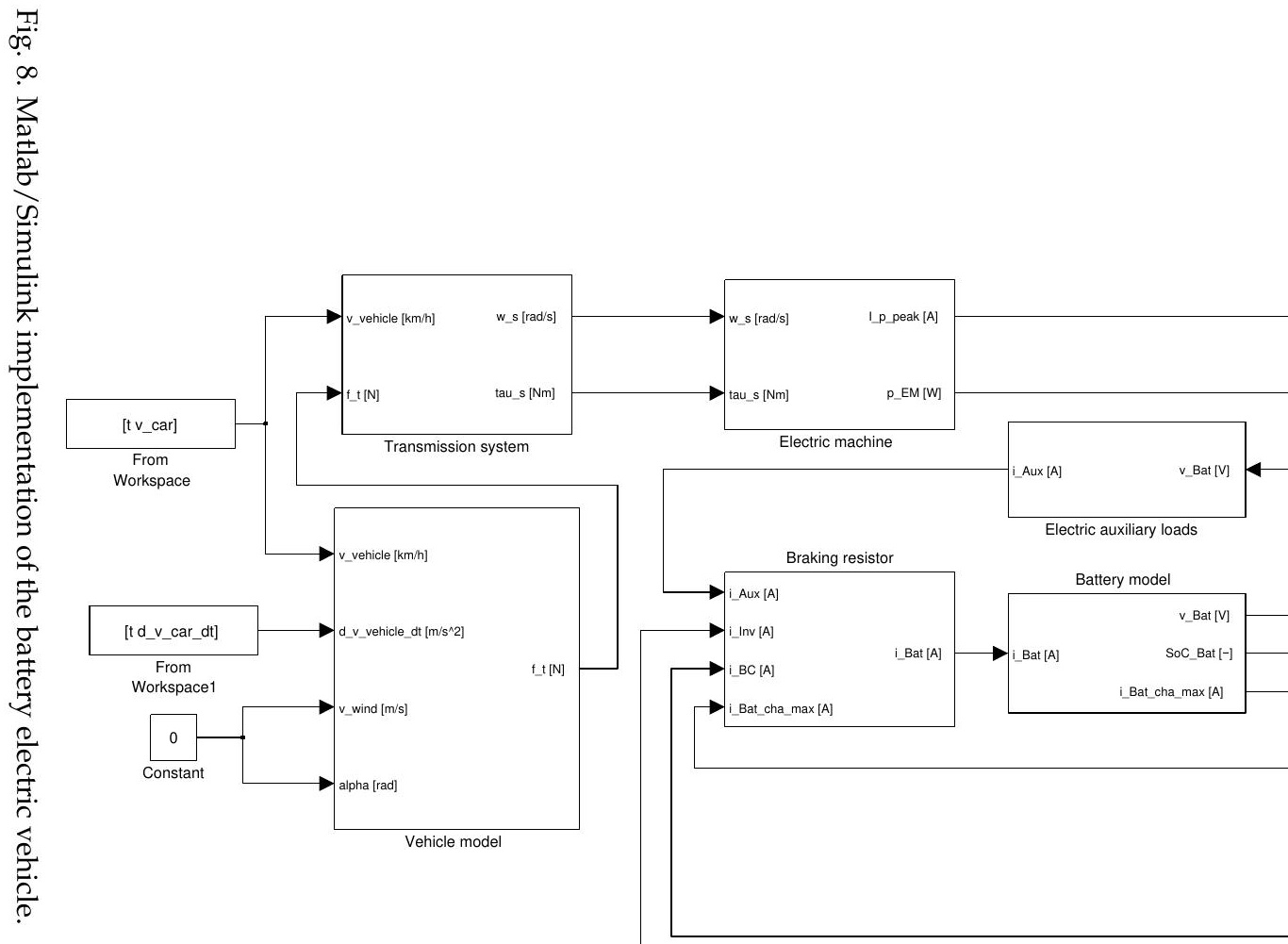


The three sub-processes in the "Simulation routine"-process are executed three times in order to make sure that parameters converges to the same values for the same input. After the "Simulation routine"-process is finish the "Calculate number of parallel strings"-process is applied. In this process the number of parallel strings $N_{\text {Bat,p }}$ is either increased or decreased. When the minimum possible number of parallel strings that fulfills both the energy and power requirements of the battery has been found the "Simulation routine"-process is executed in order to calculate the grid energy due to the final number of parallel strings.
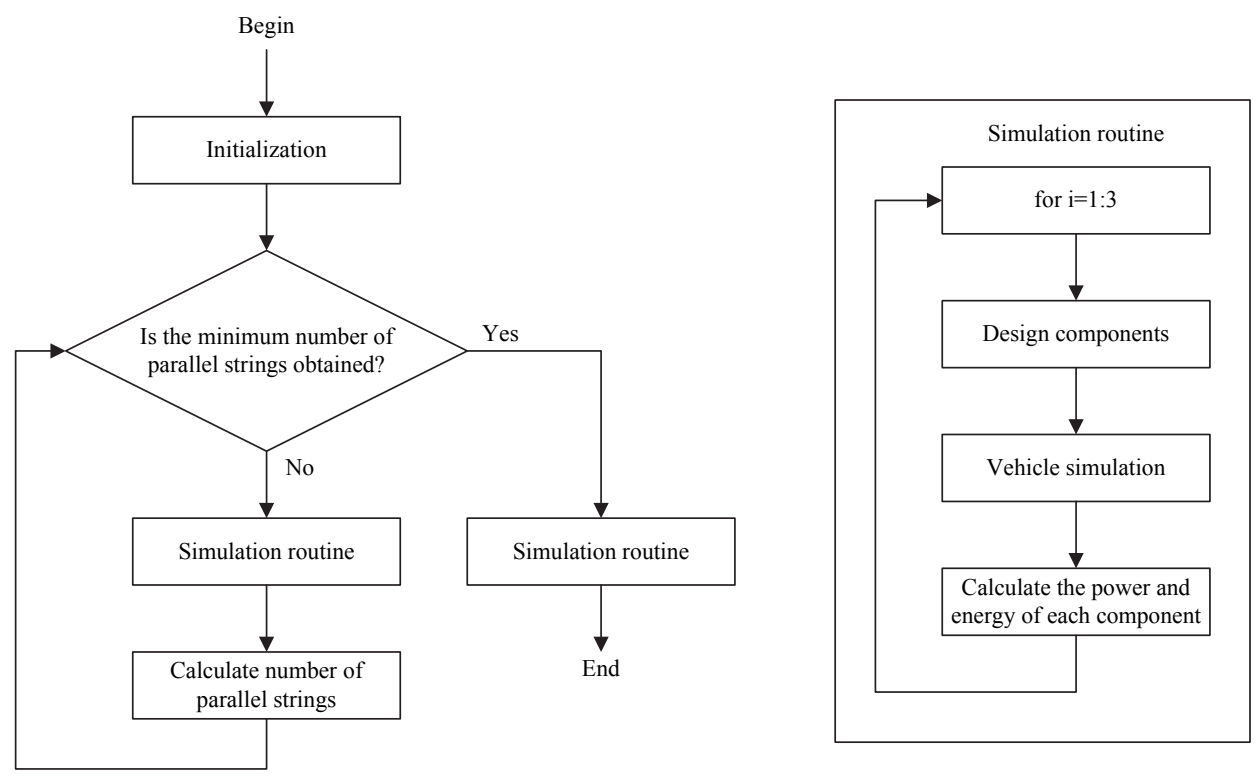

Fig. 9. Sizing procedure of the battery electric vehicle.

In principle all the energy of a battery could be used for the traction. However, in order to prolong the lifetime of the battery it is usually recommended not to charge it to more than $90 \%$ of its rated capacity and not to discharge it below $S o C_{\mathrm{Bat}, \min }=20 \%$, i.e., only $70 \%$ of the available energy is therefore utilized. In Fig. 10 it can be seen how the "Calculate number of parallel strings"-process finds the minimum number of parallel strings $N_{\text {Bat,p }}$ that fulfills both the energy and power requirements. This process is a part of the sizing procedure shown in Fig. 9. In Fig. 10(a) the minimum state-of-charge $\min \left(\mathrm{SoC}_{\mathrm{Bat}}\right)$ is shown and in Fig. 10(b) the maximum battery cell discharge current $\max \left(i_{\text {Bat,cell }}\right)$ is shown. From the figure it is understood that the first iteration is for $N_{\mathrm{Bat}, \mathrm{p}}=10$. However, both the minimum state-of-charge and maximum discharge current are satisfying their limits, i.e., $S o C_{\mathrm{Bat}, \min }=0.2$ and $I_{\mathrm{Bat}, \mathrm{max}, \mathrm{cell}}=28 \mathrm{~A}$, respectively. Therefore the number of parallel strings is reduced to $N_{B a t, p}=3$ for iteration number two. However, now the state-of-charge limit is exceeded and therefore the number of parallel strings is increased to $N_{\text {Bat,p }}=8$ for iteration three. This process continuous until iteration number six where the number of parallel strings settles to $N_{\text {Bat,p }}=6$, as this is the minimum number of parallel strings which ensures that both the state-of-charge and maximum current requirements are fulfilled. 

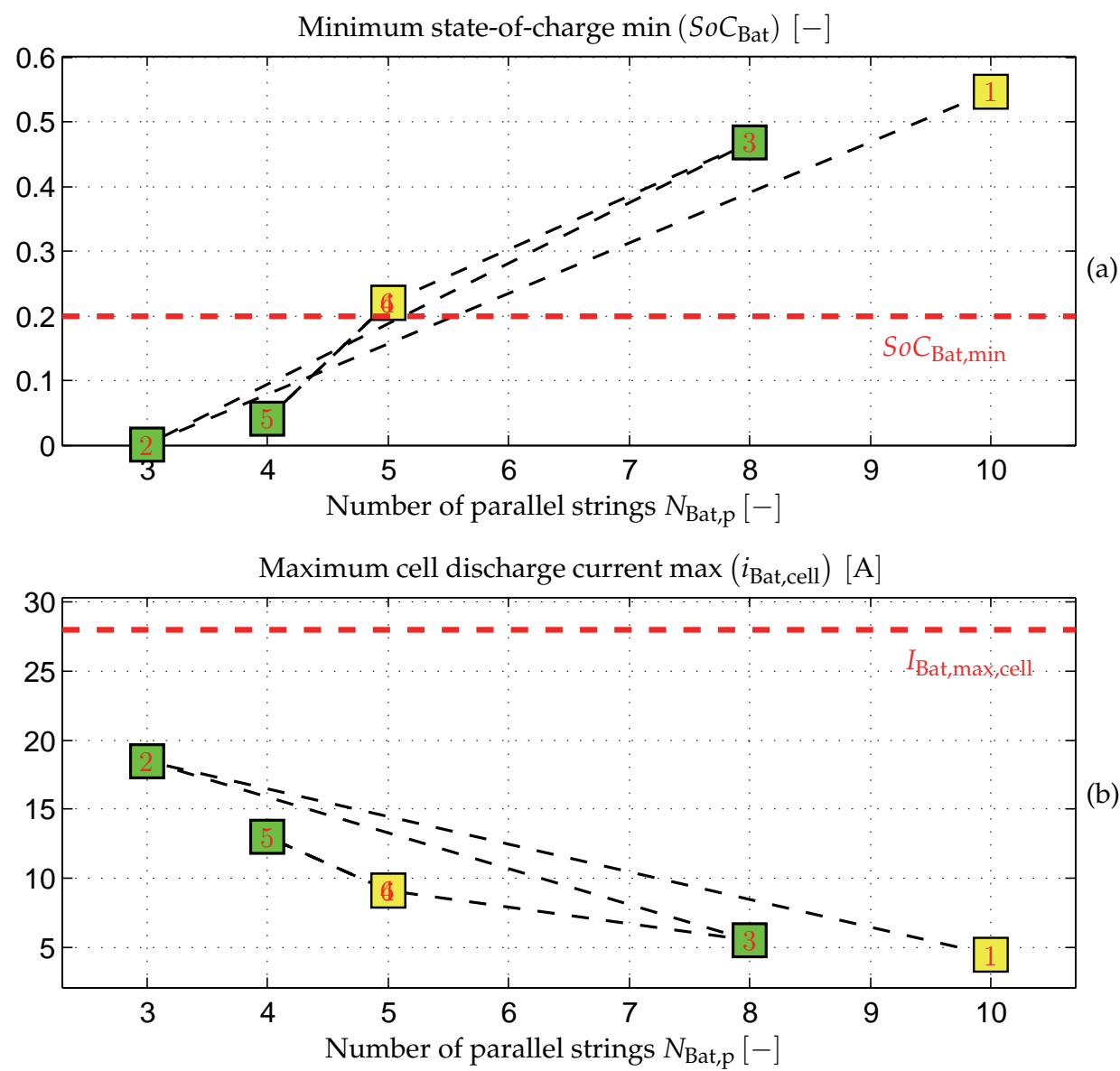

Fig. 10. Number of parallel strings $N_{\text {Bat,p }}$ due to the "Calculate number of parallel strings"-process in Fig. 9. The numbers in the green and yellow boxes indicate the iteration number of the design procedure. The yellow boxes are the first and last iteration number. (a) Minimum state-of-charge $S o C_{\mathrm{Bat}, \mathrm{min}}$. The red dashed horizontal lines indicates the minimum allowed state-of-charge. (b) Maximum cell discharge current $\max \left(i_{\text {Bat,cell }}\right)$. The dashed red horizontal line indicates the maximum allowed discharge current.

\subsubsection{Electric machine}

In order to design the machine design constraints from UQM Technologies (UQM, 2010) are applied. The machine from UQM Technologies is a brushless permanent magnet synchronous machine with the specifications in Table 3.

The phase angle between the voltage and current is not specified, but is assumed to be $\phi_{\mathrm{EM}, \text { nom }}=0.55 \mathrm{rad}$, which corresponds to a power factor of $\cos \left(\phi_{\mathrm{EM}, \mathrm{nom}}\right)=0.85$. The shaft angular velocity at (maximum power, maximum torque), (maximum power, continuous 


\begin{tabular}{|l|r|r|}
\hline Continuous shaft power & $45 \mathrm{~kW}$ \\
Peak shaft power & $P_{\mathrm{s}, \text { max,UQM }}$ & $75 \mathrm{~kW}$ \\
Maximum speed & $n_{\mathrm{s}, \max }$ & $8000 \mathrm{rpm}$ \\
Shaft speed at peak torque and power & $\eta_{\mathrm{s}, \mathrm{corner}}$ & $3000 \mathrm{rpm}$ \\
Number of poles (Jensen et al., 2009) & $P$ & 18 \\
Continuous shaft torque & $\tau_{\mathrm{s}, \mathrm{cont}, \mathrm{UQM}}$ & $150 \mathrm{Nm}$ \\
Peak shaft torque & $\tau_{\mathrm{s}, \mathrm{max}, \mathrm{UQM}}$ & $240 \mathrm{Nm}$ \\
Efficiency at maximum shaft power and continuous torque & $\eta_{\mathrm{EM}, \mathrm{a}}$ & $94 \%$ \\
Efficiency at maximum shaft power and maximum speed & $\eta_{\mathrm{EM}, \mathrm{b}}$ & $90 \%$ \\
\hline
\end{tabular}

Table 3. Specifications of UQM PowerPhase 75 (UQM, 2010) from UQM Technologies.

torque), and maximum speed are therefore

$$
\begin{aligned}
\omega_{\mathrm{s}, \text { corner }} & =\frac{n_{\mathrm{s}, \mathrm{corner}}}{60 \mathrm{~s} / \min } 2 \pi=314.2 \mathrm{rad} / \mathrm{s} \\
\omega_{\mathrm{s}, \text { nom }} & =\frac{P_{\mathrm{s}, \max , \mathrm{UQM}}}{\tau_{\mathrm{s}, \mathrm{cont}, \mathrm{UQM}}}=500 \mathrm{rad} / \mathrm{s} \\
\omega_{\mathrm{s}, \max } & =\frac{n_{\mathrm{s}, \max }}{60 \mathrm{~s} / \min } 2 \pi=837.8 \mathrm{rad} / \mathrm{s} .
\end{aligned}
$$

The relationship between the maximum and continuous shaft torque can be defined as

$$
a_{\mathrm{EM}}=\frac{\tau_{\mathrm{s}, \mathrm{cont}, \mathrm{UQM}}}{\tau_{\mathrm{s}, \mathrm{max}, \mathrm{UQM}}}=1.6
$$

It is only possible to have the maximum shaft torque of a PMSM as long as the product of the shaft torque and angular velocity is below the maximum shaft power due to the voltage induced by the permanent magnet. For a PMSM with a given shaft peak torque $\tau_{\mathrm{s}, \max }$ the speed-torque contour can be written as

$$
\begin{aligned}
& P_{\mathrm{s}, \max }=\tau_{\mathrm{s}, \max } \omega_{\mathrm{s}, \text { corner }} \\
& \tau_{\mathrm{s}, \text { limit }}=\left\{\begin{array}{l}
\tau_{\mathrm{s}, \max }, \omega_{\mathrm{s}} \leq \omega_{\mathrm{s}, \text { corner }} \\
\frac{P_{\mathrm{s} \text { max }}}{\omega_{\mathrm{s}}}, \omega_{\mathrm{s}}>\omega_{\mathrm{s}, \text { corner }} .
\end{array}\right.
\end{aligned}
$$

The peak shaft torque $\tau_{\mathrm{s}, \max }$ is selected in such a way that the $\left(\tau_{\mathrm{s}}, \omega_{\mathrm{s}}\right)$-output from the Matlab/Simulink simulation is below the shaft torque contour $\tau_{\mathrm{s}, \text { limit }}$ calculated by Equation 46.

By trial-and-error-method it turns out that if the coulomb torque and viscous friction are responsible for $2 \%$ and $6 \%$, respectively, of the power loss at maximum speed and power, the maximum efficiency is located around the nominal point of operation. Therefore

$$
\begin{aligned}
\tau_{\mathrm{c}} & =\frac{0.02}{\omega_{\mathrm{s}}} \frac{P_{\mathrm{s}, \max }}{\eta_{\mathrm{EM}, \mathrm{b}}} \\
B_{\mathrm{V}} & =\frac{0.06}{\omega_{\mathrm{s}}^{2}} \frac{P_{\mathrm{s}, \max }}{\eta_{\mathrm{EM}, \mathrm{b}}} .
\end{aligned}
$$

The nominal electro mechanical torque is:

$$
\begin{aligned}
\tau_{\mathrm{s}, \text { cont }} & =\frac{\tau_{\mathrm{s}, \max }}{a_{\mathrm{EM}}} \\
\tau_{\mathrm{e}, \text { cont }} & =\tau_{\mathrm{c}}+B_{\mathrm{v}} \omega_{\mathrm{s}, \text { nom }}+\tau_{\mathrm{s}, \text { cont }} .
\end{aligned}
$$


The machine will be designed at nominal speed $\omega_{\mathrm{s}, \text { nom, }}$ maximum power $P_{\mathrm{s}, \max }$, and minimum bus voltage $V_{\mathrm{Bus}, \mathrm{min}}$. The speed is approximately proportional to the terminal voltage. At the minimum bus voltage the machine should be able run at maximum speed with a modulation index $m_{\mathrm{i}}=1$. Because the machine is designed at nominal speed, but at the minimum battery voltage, the modulation index is

$$
m_{\mathrm{i}, \mathrm{nom}}=\frac{\omega_{\mathrm{s}, \mathrm{nom}}}{\omega_{\mathrm{s}, \max }}=0.3581 .
$$

The voltages of the machine are therefore:

$$
\begin{aligned}
\hat{V}_{\mathrm{p}, \text { nom }} & =m_{\mathrm{i}, \text { nom }} \frac{V_{\mathrm{Bat}, \mathrm{min}}}{2} \\
V_{\mathrm{d}, \text { nom }} & =-\hat{V}_{\mathrm{p}, \text { nom }} \sin \left(\phi_{\mathrm{EM}, \text { nom }}\right) \\
V_{\mathrm{q}, \text { nom }} & =\hat{V}_{\mathrm{p}, \text { nom }} \cos \left(\phi_{\mathrm{EM}, \text { nom }}\right) .
\end{aligned}
$$

Several control properties of the PMSM can be applied. Due to its simple implementation the $I_{\mathrm{d}}=0$ property is selected even though the reluctance then cannot be utilized. Therefore, when using $I_{\mathrm{d}}=0$ control the machine parameters can be calculated as follows:

$$
\begin{aligned}
P_{\mathrm{EM}, \mathrm{max}} & =\frac{P_{\mathrm{s}, \mathrm{max}}}{\eta_{\mathrm{EM}, \mathrm{a}}} \\
I_{\mathrm{q}, \mathrm{cont}} & =\frac{2}{3} \frac{P_{\mathrm{EM}, \mathrm{max}}}{V_{\mathrm{q}, \mathrm{nom}}} \\
\lambda_{\mathrm{pm}} & =\frac{2}{3} \frac{2}{P} \frac{\tau_{\mathrm{e}, \mathrm{cont}}}{I_{\mathrm{q}, \mathrm{cont}}} \\
\omega_{\mathrm{e}, \text { nom }} & =\omega_{\mathrm{s}, \text { nom } \frac{P}{2}}=4500 \mathrm{rad} / \mathrm{s} \\
L_{\mathrm{q}} & =-\frac{V_{\mathrm{d}, \text { nom }}}{\omega_{\mathrm{e}, \text { nom }} I_{\mathrm{q}, \mathrm{cont}}} \\
R_{\mathrm{s}} & =\frac{V_{\mathrm{q}, \text { nom }}-\omega_{\mathrm{e}, \text { nom }} \lambda_{\mathrm{pm}}}{I_{\mathrm{q}, \text { cont }}} .
\end{aligned}
$$

The efficiency of the machine for different torque-speed characteristics can be seen in Fig. 11 . It is seen that the efficiency is highest at continuous torque $\tau_{\mathrm{s} \text {, cont }}$ and nominal speed $n_{\mathrm{s}, \mathrm{nom}}$. A common mistake in electric vehicle modeling is to assume a fixed efficiency of the components and it can be understood from Fig. 11 that wrong conclusions therefore can be made if the electric machines not is operating in a sufficient point of operation. The corner speed $n_{\mathrm{s}, \mathrm{corner}}$ nominal speed $n_{\mathrm{s}, \text { nom }}$, maximum speed $n_{\mathrm{s} \text {, max }}$, continuous torque $\tau_{\mathrm{s}, \text { cont }}$, peak torque $\tau_{\mathrm{s}, \max }$, and the torque contour $\tau_{\mathrm{s}, \text { limit }}$ are also shown in the figure.

\subsubsection{Transmission}

The maximum speed of the electric machine is $n_{\mathrm{s}, \max }=8000 \mathrm{rpm}$. The required gear ratio of the differential is therefore

$$
G=\frac{n_{\mathrm{s}, \max }}{V_{\mathrm{car}, \max }} \frac{2 \pi}{60} \frac{r_{\mathrm{w}}}{1.1}
$$




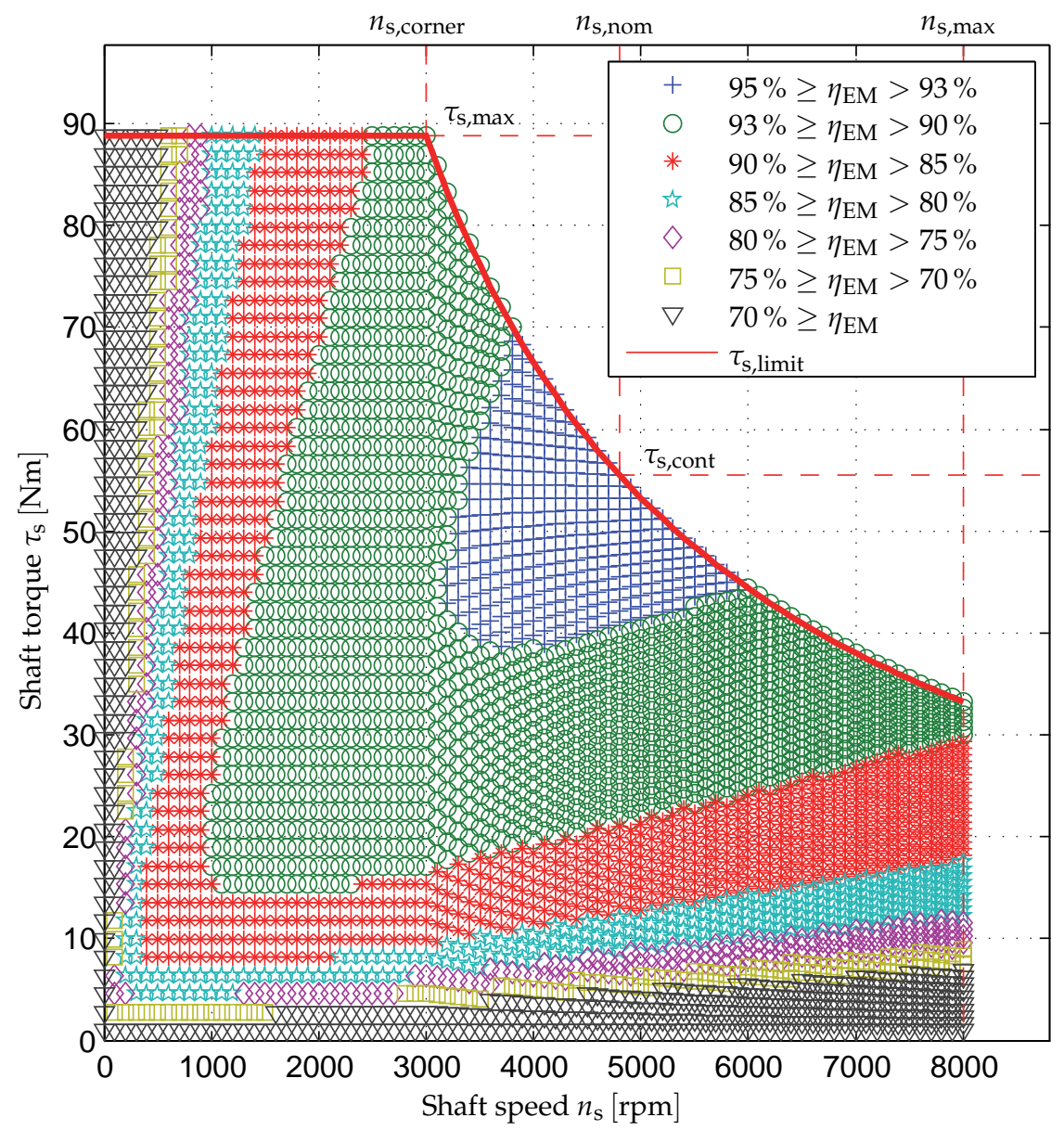

Fig. 11. Efficiency map of the electric machine.

From Equation 61 it is seen that the differential is designed with a $10 \%$ buffer of the maximum speed of the car.

\subsubsection{Rectifier}

It is expected that most of the charging of the vehicle will take place at private homes, where the maximum RMS-current is $I_{\text {Grid,max }}=16 \mathrm{~A}$. The maximum grid power and rectifier current are therefore

$$
\begin{aligned}
P_{\text {Grid,max }} & =\frac{3 \sqrt{3}}{\pi} V_{\mathrm{LL}} I_{\text {Grid,max }}=10.6 \mathrm{~kW} \\
I_{\mathrm{RF}, \max } & =\sqrt{\frac{3}{2}} I_{\text {Grid,max }}=19.6 \mathrm{~A} .
\end{aligned}
$$


It is assumed that the rectifier has an efficiency of $\eta_{\mathrm{RF}, \text { nom }}=0.98$ at maximum grid power. The switch-on resistance can therefore be calculated from Equation 36:

$$
\begin{gathered}
P_{\mathrm{RF}, \max }=\eta_{\mathrm{RF}, \text { nom }} P_{\mathrm{Grid}, \max }=P_{\mathrm{Grid}, \max }-\left(2 R_{\mathrm{RF}} I_{\mathrm{RF}, \max }^{2}+2 V_{\mathrm{th}, \mathrm{RF}} I_{\mathrm{RF}, \max }\right) \\
\mathbb{\Downarrow} \\
R_{\mathrm{RF}}=\frac{P_{\mathrm{Grid}, \max }\left(1-\eta_{\mathrm{RF}, \text { nom }}\right)-2 V_{\mathrm{th}, \mathrm{RF}} I_{\mathrm{RF}, \max }}{2 I_{\mathrm{RF}, \max }^{2}}=199 \mathrm{~m} \Omega .
\end{gathered}
$$

\subsubsection{Boost converter}

It is assumed that the boost converter has efficiency $\eta_{\mathrm{BC}, \text { nom }}=0.98$ at maximum power. The maximum power of the boost converter is therefore

$$
P_{\mathrm{BC}, \max }=P_{\mathrm{RF}, \max } \eta_{\mathrm{BC}, \mathrm{nom}} .
$$

The threshold voltage is $V_{\mathrm{th}, \mathrm{BC}}=1.5 \mathrm{~V}$. From Equation 31 the resistance of the boost converter is therefore

$$
\begin{aligned}
& P_{\mathrm{RF}, \text { max }}=\eta_{\mathrm{BC}, \mathrm{nom}} P_{\mathrm{RF}, \text { max }}+R_{\mathrm{BC}} I_{R F, \text { max }}^{2}+V_{\mathrm{th}, \mathrm{BC}} I_{\mathrm{RF}, \max } \\
& R_{\mathrm{BC}}=\frac{P_{\mathrm{RF}, \text { max }}\left(1-\eta_{\mathrm{BC}, \text { rat }}\right)-V_{\mathrm{th}, \mathrm{BC}} I_{\mathrm{RF}, \max }}{I_{\mathrm{RF}, \text { max }}^{2}}=475 \Omega .
\end{aligned}
$$

It might be noticed that the values of the resistances of the rectifier and boost converter are higher than one would expect. However, this is because it is assumed that all the loss is due to the threshold voltage and resistance of the switches and diodes.

\subsubsection{Inverter}

The inverter is also designed at the maximum power of the electric machine and at minimum battery voltage. However, the inverter is designed at the peak shaft torque instead of at the maximum speed. The inverter is assumed to have an efficiency of $\eta_{\text {Inv,nom }}=0.98$ at this point of operation. The loss $P_{\text {Inv,loss, max }}$ and resistance $R_{\text {Inv }}$ of the inverter are therefore

$$
\begin{aligned}
P_{\text {Inv,loss,max }} & =\frac{1-\eta_{\text {Inv,nom }}}{\eta_{\text {Inv,nom }}} P_{\mathrm{EM}, \max } \\
\tau_{\mathrm{e}, \max } & =\tau_{\mathrm{c}}+B_{\mathrm{v}} \omega_{\mathrm{s}, \text { corner }}+\tau_{\mathrm{s}, \max } \\
I_{\mathrm{q}, \max } & =\frac{2}{3} \frac{2}{P} \frac{\tau_{\mathrm{e}, \max }}{\lambda_{\mathrm{pm}}} \\
R_{\text {Inv }} & =\frac{P_{\text {Inv,loss,max}}-\frac{6}{\pi} V_{\mathrm{th}, \text { Inv }} I_{\mathrm{q}, \max }}{\frac{3}{2} I_{\mathrm{q}, \max }^{2}} .
\end{aligned}
$$

The threshold voltage is assumed to be $V_{\mathrm{th}, \mathrm{Inv}}=1 \mathrm{~V}$. 


\subsection{Battery charging control}

During the charging of the battery, i.e., both due to the regenerative braking and the grid, it is very important that the maximum battery charging current and voltage not are exceeded. The maximum allowed cell charging current can be calculated from the inner and outer voltage of the battery cell, i.e.,

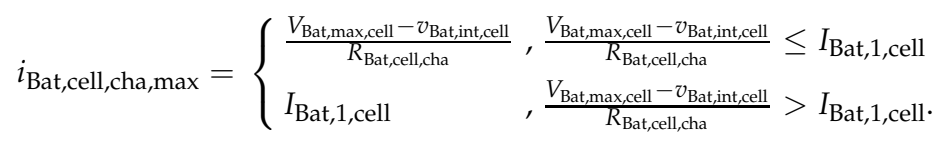

In Equation 73 it is insured that neither the maximum allowed voltage or current are exceeded. The battery pack consist of $N_{\text {Bat, }}$ series connected cells and $N_{\text {Bat,p }}$ parallel connected strings. The total voltage and current of the battery pack can therefore be calculated as

$$
\begin{aligned}
v_{\text {Bat }} & =N_{\text {Bat, } \mathrm{s}} v_{\text {Bat,cell }} \\
i_{\text {Bat }} & =N_{\text {Bat, } \mathrm{p}} i_{\text {Bat,cell }} \\
i_{\text {Bat,cha,max }} & =N_{\text {Bat,p }} i_{\text {Bat,cell,cha,max }} .
\end{aligned}
$$

During the charging of the battery the battery cell voltage $v_{\text {Bat,cell }}$ should not exceed $V_{\text {Bat,max,cell }}=4.2 \mathrm{~V}$ and the maximum cell charging current should not be higher than $I_{\text {Bat, } 1, \text { cell }}=7 \mathrm{~A}$ (Saft, 2010). In order to charge the battery as fast as possible either the maximum voltage or maximum current should be applied to the battery. The requested battery charging current, i.e., the output current of the boost converter $i_{\mathrm{BC}}$, is therefore

$$
i_{\mathrm{BC}}^{*}=i_{\mathrm{Bat}, \mathrm{cha}, \max }
$$

which means that the requested output power of the boost converter is

$$
p_{\mathrm{BC}}^{*}=v_{\mathrm{Bat}} i_{\mathrm{BC}}^{*} .
$$

The requested charging current insures that neither the maximum allowed voltage or current are exceeded. However, for a big battery pack the required charging power might be so high that a special charging station is necessary.

The requested input current of the boost converter, i.e., the rectifier current $i_{\mathrm{RF}}$, can be calculated by Equation 31 and 78:

$$
i_{\mathrm{RF}}^{*}=\frac{-\left(V_{\mathrm{th}, \mathrm{BC}}-v_{\mathrm{RF}}\right)-\sqrt{\left(V_{\mathrm{th}, \mathrm{BC}}-v_{\mathrm{RF}}\right)^{2}-4 R_{\mathrm{BC}} p_{\mathrm{BC}}^{*}}}{2 R_{\mathrm{BC}}} .
$$

The grid RMS-current can therefore from Equation 34 be calculated as

$$
I_{\text {Grid }}=\left\{\begin{array}{l}
\sqrt{\frac{2}{3}} i_{\mathrm{RF}}^{*}, \sqrt{\frac{2}{3}} i_{\mathrm{RF}}^{*}<I_{\mathrm{Grid}, \max } \\
I_{\mathrm{Grid}, \max }, \sqrt{\frac{2}{3}} i_{\mathrm{RF}}^{*} \geq I_{\mathrm{Grid}, \max }
\end{array}\right.
$$




\begin{tabular}{|l|l|r|}
\hline Glider mass & $M_{\text {glider }}$ & $670 \mathrm{~kg}$ \\
Wheel radius & $r_{\mathrm{w}}$ & $0.2785 \mathrm{~m}$ \\
Front area & $A_{\text {front }}$ & $1.68 \mathrm{~m}^{2}$ \\
Aerodynamic drag coefficient & $C_{\text {drag }}$ & 0.3 \\
\hline
\end{tabular}

Table 4. Parameters of the vehicle used for the case study.

Thereby it is ensured that the maximum RMS grid current is not exceeded. The actual values can therefore be obtained by calculating backwards, i.e.,

$$
\begin{aligned}
i_{\mathrm{RF}} & =\sqrt{\frac{3}{2}} I_{\mathrm{Grid}} \\
p_{\mathrm{RF}} & =v_{\mathrm{RF}} i_{\mathrm{RF}} \\
p_{\mathrm{BC}} & =p_{\mathrm{RF}}-R_{\mathrm{BC}} i_{\mathrm{RF}}^{2}-V_{\mathrm{th}, \mathrm{BC}} i_{\mathrm{RF}} \\
i_{\mathrm{BC}} & =\frac{p_{\mathrm{BC}}}{v_{\mathrm{Bat}}} .
\end{aligned}
$$

\section{Case study}

\subsection{Driving cycle}

When different cars are compared in terms of energy consumption a standard driving cycle is used. An often used driving cycle is the New European Driving Cycle (NEDC) as this driving cycle contains both city driving with several start-and-stops and motorway driving, i.e., it is a good representation of a realistic driving environment. The NEDC has a maximum speed of $120 \mathrm{~km} / \mathrm{h}$, an average speed of $33.2 \mathrm{~km} / \mathrm{h}$, a duration of $1184 \mathrm{~s}$, and a length of $10.9 \mathrm{~km}$. The NEDC profile can be seen in Fig. 12. The input to the simulation will be the NEDC repeated 14 times as this should provide a driving distance of $153 \mathrm{~km}$ which is assumed to be an acceptable driving distance.

\subsection{Vehicle parameters}

The energy consumption of a given vehicle depend on the physical dimensions and total mass of the vehicle. For this case study the parameters in Table 4 are used. The glider mass is the mass of the vehicle without motor, battery, power electronics, etc. It might be understood from the parameters in Table 4 that it is a rather small vehicle, i.e., similar to a Citroën C1.

\subsection{Results}

In Fig. 13 the battery state-of-charge, current, voltage, and the power of the grid and battery can be seen. It is understood from Fig. 13(a) that the battery is designed due to its energy requirement rather than the power requirement as the state-of-charge reaches the minimum allowed value of $S o C_{\text {Bat,min }}=0.2$. In Fig. 13(b) and (c) the battery current and voltage are shown, respectively. It is seen that when the current becomes higher the voltage becomes lower as the power should be the same. In Fig. 13(d) the battery and grid power are shown. It is seen that the charging of the battery is limited by the maximum allowed grid power $P_{\text {Grid,max }}$. After approximately two hours the battery reaches the maximum voltage, and it is therefore seen that the battery then is charged under constant-voltage approach, which means that the battery current and power and grid power slowly are decreased until the battery reaches its initial state-of-charge value. 


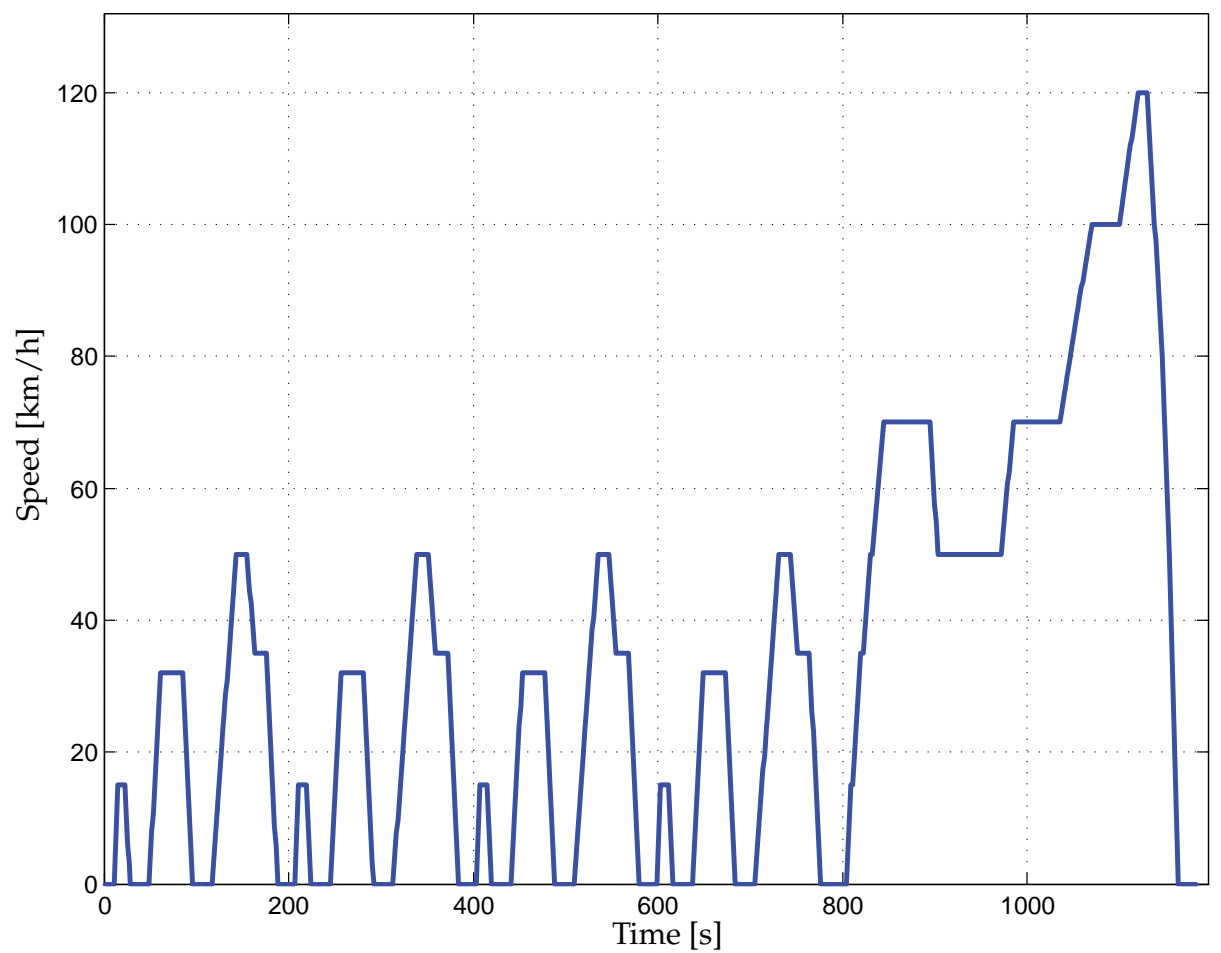

Fig. 12. New European Driving Cycle (NEDC). This driving cycle will be repeated 14 times and thereby serving as the input profile of the Matlab/Simulink simulation model.

Due to the minimum battery pack voltage requirement $N_{\text {Bat }, \mathrm{s}}=216$ series connected battery cells are required. The chosen vehicle is designed to be able to handle 14 repetitions of the NEDC. From Fig. 10 it is understood that $N_{\text {Bat, } p}=5$ parallel strings are demanded in order to fulfill this requirement. This means that the battery pack has a capacity of

$$
E_{\text {Bat }}=\frac{V_{\text {Bat,nom,cell }} N_{\text {Bat }, \mathrm{s}} Q_{\text {Bat }, 1, \text { cell }} N_{\text {Bat }, \mathrm{s}}}{1000 \mathrm{Wh} / \mathrm{kWh}}=28.0 \mathrm{kWh} .
$$

The energy distribution of the vehicle can be seen in Fig. 14. During the 14 NEDC repetitions $E_{\mathrm{t}}=11.2 \mathrm{kWh}$ is delivered to the surface between the driving wheels and the road, but $E_{\text {Grid }}=22.7 \mathrm{kWh}$ charging energy is taken from the grid. This means that only $49 \%$ of the charging energy from the grid is used for the traction and that the grid energy consumption is $148.3 \mathrm{Wh} / \mathrm{km}$. The rest of the energy is lost in the path between the wheels and the grid. The auxiliary loads are responsible for the biggest energy loss at $17 \%$. However, it is believed that this can be reduced significant by using diodes for the light instead of bulbs, and to use heat pumps for the heating instead of pure resistive heating.

The battery is responsible for the second largest energy waist as $14 \%$ of the grid energy is lost in the battery. The battery was only designed to be able to handle the energy and power requirements. However, in order to reduce the loss of the battery it might be beneficial to oversize the battery as the battery peak currents then will become closer to its nominal current 


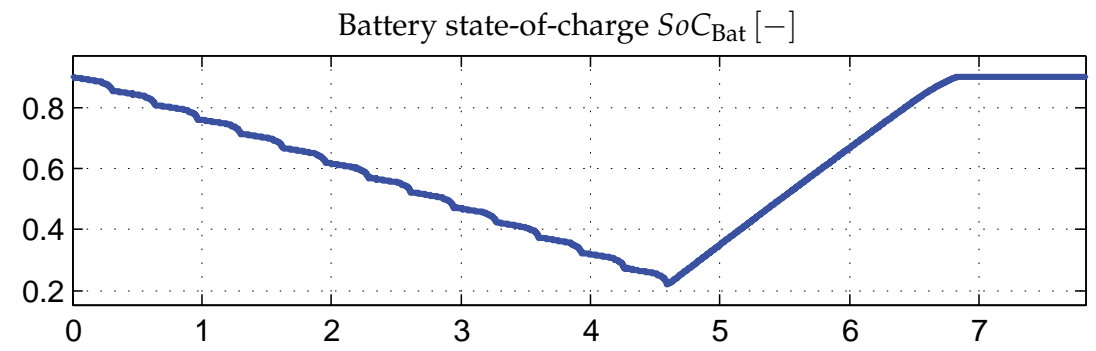

(a)

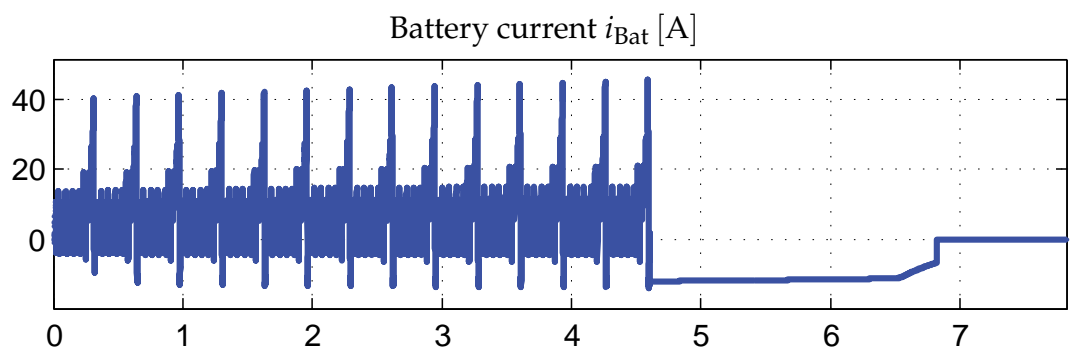

(b)

Battery voltage $v_{\text {Bat }}[\mathrm{V}]$

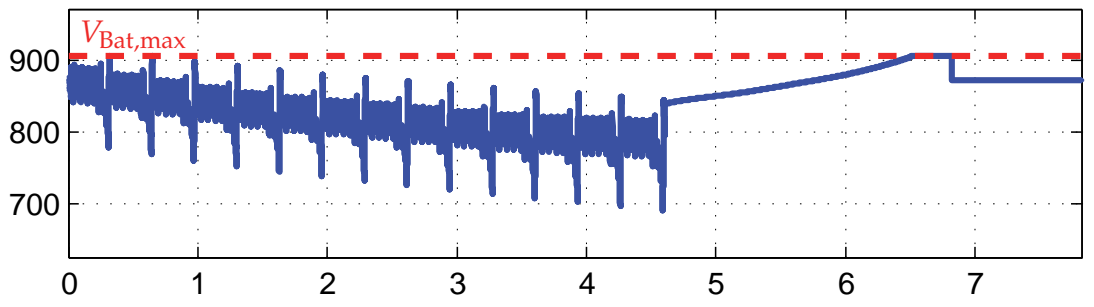

(c)

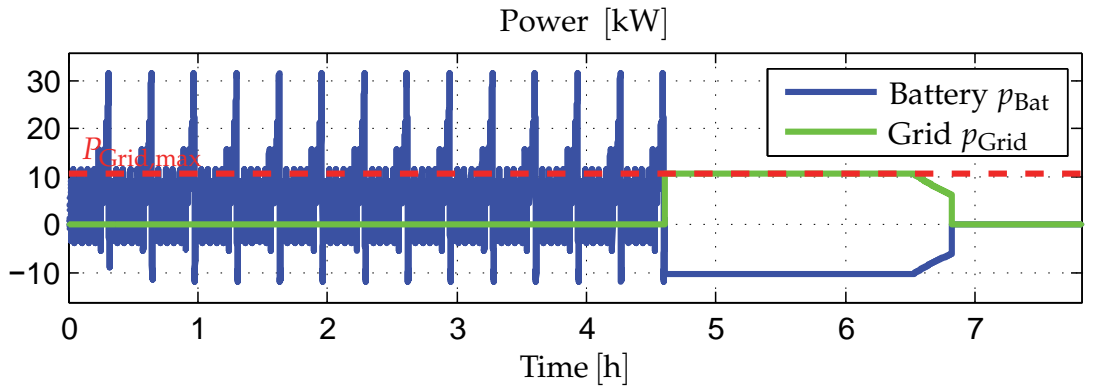

(d)

Fig. 13. Simulation results of the vehicle with 14 repeated NEDC cycles as input. (a) Battery state-of-charge. (b) Battery current. (c) Battery voltage. (d) Power of the battery and grid. 
which will reduce the negative influence of the peukert phenomena. However, a heavier battery will also increase the traction power, so the gained reduction in battery loss should be higher than the increased traction power. A bigger battery will of course also make the vehicle more expensive, but these issues are left for future work.

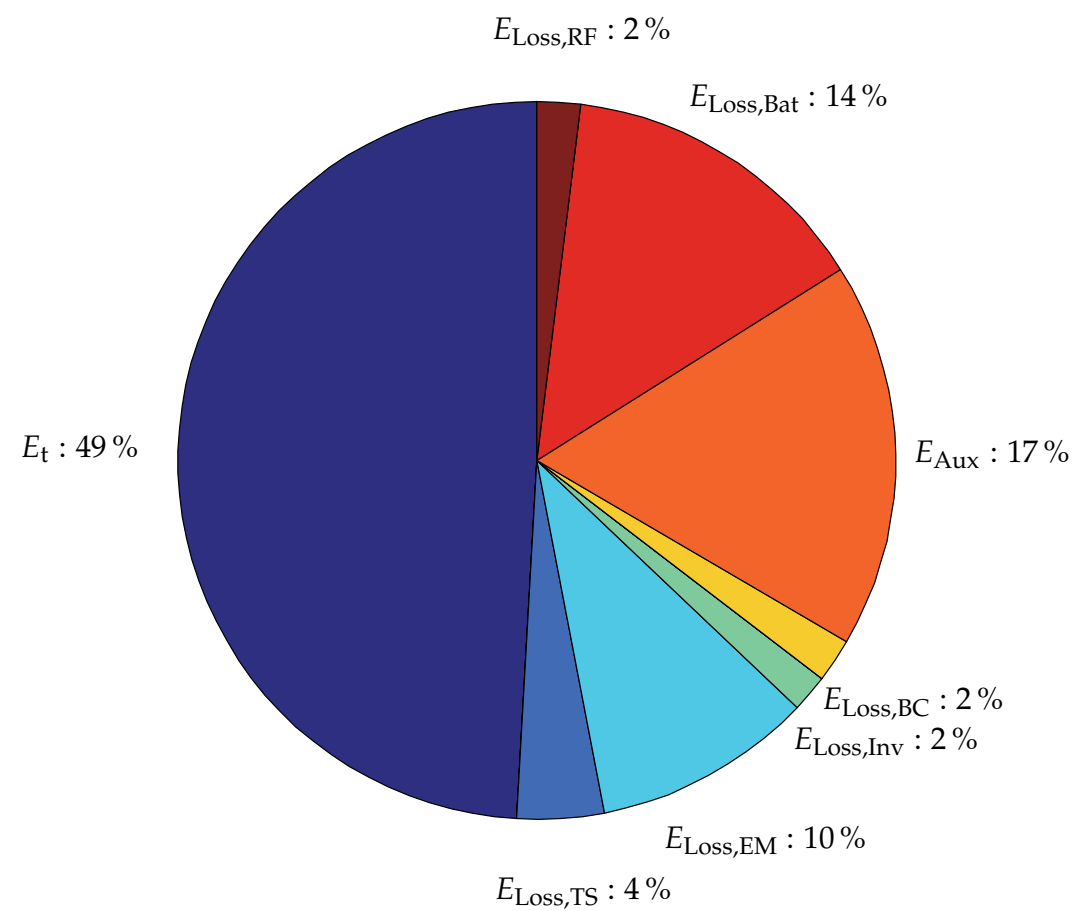

Fig. 14. Energy distribution in the vehicle relative to the grid energy.

\section{Conclusion}

In this chapter a battery electric vehicle have been modeled and designed. The battery of the electric vehicle is designed in such a way that both the power and energy requirements are fulfilled for a given driving cycle. The design procedure is an iterative process as the power flow inside the vehicle depends on the parameters of each component of the power system between the grid and driving wheels. The loss of each component in the vehicle depend on the internal states of the vehicle, i.e., the voltages, currents, speed, torques, and state-of-charge. These states have been included in the modeling in order to obtain a realistic energy calculation of the vehicle. A case study with a small vehicle undergoing 14 driving cycles of type NEDC resulted in a grid energy consumption of $148.3 \mathrm{Wh} / \mathrm{km}$ with an efficiency of $49 \%$ from the grid to the driving wheels. However, a relatively big part of the energy loss is due to the auxiliary loads, e.g., light, safety systems, comfort systems, etc., and the battery. For this work the only design constraint of the battery was the voltage limit, and the energy and power requirements. For future work it is recommended also to include the cost and overall efficiency as design parameters. It is also suggested to investigate how the loss due to the auxiliary loads can be reduced. 


\section{References}

Casanellas, F. (1994). Losses in pwm inverters using igbts, IEE Proceedings - Electric Power Applications 141(5): 235 - 239.

Chan, C. C., Bouscayrol, A. \& Chen, K. (2010). Electric, hybrid, and fuel-cell vehicles: Architectures and modeling, IEEE Transactions on Vehicular Technology 59(2): 589 598.

Ehsani, M., Gao, Y., Gay, S. E. \& Emadi, A. (2005). Modern Electric, Hybrid Electric, and Fuel Cell Vehicles - Fundamentals, Theory, and Design, first edn, CRC Press LLC.

Emadi, A. (2005). Handbook of Automotive Power Electronics and Motor Drives, first edn, Taylor \& Francis.

Gao, D. W., Mi, C. \& Emadi, A. (2007). Modeling and simulation of electric and hybrid vehicles, Proceedings of the IEEE 95(4): 729 - 745.

Jensen, K. K., Mortensen, K. A., Jessen, K., Frandsen, T., Runólfsson, G. \& Thorsdóttir, T. (2009). Design of spmsm drive system for renault kangoo, Aalborg University .

Lukic, S. \& Emadi, A. (2002). Performance analysis of automotive power systems: effects of power electronic intensive loads and electrically-assisted propulsion systems, Proc. of IEEE Vehicular Technology Conference (VTC) 3: 1835 - 1839.

Mapelli, F. L., Tarsitano, D. \& Mauri, M. (2010). Plug-in hybrid electric vehicle: Modeling, prototype realization, and inverter losses reduction analysis, IEEE Transactions on Industrial Electronics 57(2): 598 - 607.

Mohan, N., Underland, T. M. \& Robbins, W. P. (2003). Power electronics, third edn, John Wiley.

Saft (2010). Saftbatteries. URL: http://www.saftbatteries.com

Schaltz, E. (2010). Design of a Fuel Cell Hybrid Electric Vehicle Drive System, Department of Energy Technology, Aalborg University.

UQM (2010). Uqm technologies. URL: http://www.uqm.com 


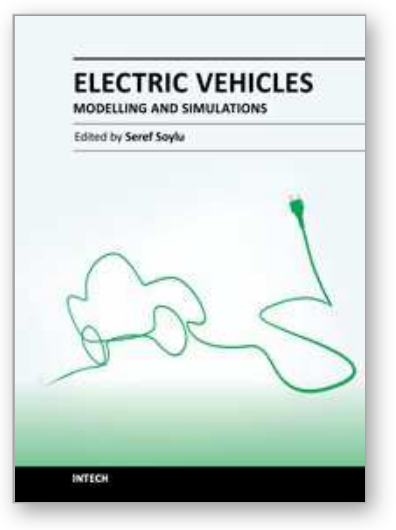

\author{
Electric Vehicles - Modelling and Simulations \\ Edited by Dr. Seref Soylu
}

ISBN 978-953-307-477-1

Hard cover, 466 pages

Publisher InTech

Published online 12, September, 2011

Published in print edition September, 2011

In this book, modeling and simulation of electric vehicles and their components have been emphasized chapter by chapter with valuable contribution of many researchers who work on both technical and regulatory sides of the field. Mathematical models for electrical vehicles and their components were introduced and merged together to make this book a guide for industry, academia and policy makers.

\title{
How to reference
}

In order to correctly reference this scholarly work, feel free to copy and paste the following:

Erik Schaltz (2011). Electrical Vehicle Design and Modeling, Electric Vehicles - Modelling and Simulations, Dr. Seref Soylu (Ed.), ISBN: 978-953-307-477-1, InTech, Available from:

http://www.intechopen.com/books/electric-vehicles-modelling-and-simulations/electrical-vehicle-design-andmodeling

\section{INTECH}

open science | open minds

\section{InTech Europe}

University Campus STeP Ri

Slavka Krautzeka 83/A

51000 Rijeka, Croatia

Phone: +385 (51) 770447

Fax: +385 (51) 686166

www.intechopen.com

\section{InTech China}

Unit 405, Office Block, Hotel Equatorial Shanghai

No.65, Yan An Road (West), Shanghai, 200040, China

中国上海市延安西路65号上海国际贵都大饭店办公楼 405 单元

Phone: +86-21-62489820

Fax: +86-21-62489821 
(C) 2011 The Author(s). Licensee IntechOpen. This chapter is distributed under the terms of the Creative Commons Attribution-NonCommercialShareAlike-3.0 License, which permits use, distribution and reproduction for non-commercial purposes, provided the original is properly cited and derivative works building on this content are distributed under the same license. 